\title{
State Support for Families with Children during the COVID-19 Pandemic in Russia: Institutional Grammar Tool Analysis
}

\author{
Anna Bagirova \\ Ural Federal University, \\ Mira Street, 19, Yekaterinburg, Sverdlovsk Oblast, 620002 Russia \\ Evgeniya Kuznetsova \\ Ural Federal University, \\ Mira Street, 19, Yekaterinburg, Sverdlovsk Oblast, 620002 Russia \\ Natalia Blednova \\ Ural Federal University, \\ Mira Street, 19, Yekaterinburg, Sverdlovsk Oblast, 620002 Russia \\ cross'refhttp://dx.doi.org/10.5755/j01.ppaa.20.3.29198
}

\begin{abstract}
The COVID-19 pandemic is characterised by active law-making processes aimed at health care and support of different categories of population in many countries in the world. Starting from 2019, due to negative demographic trends, Russia has experienced the active transformation of the state support system for families having children. This trend has strengthened during the pandemic. Our research aims to analyse the internal characteristics of the family policy, namely the state support for families having children, during the year preceding pandemic and within the pandemic period. We consider the dynamics of the family policy architecture by means of Institutional Grammar Tool (IGT) analysis and demonstrate the opportunities for using the results of such analyses in the highly dynamic situation of the COVID-19 pandemic.

We analysed 11 federal legal acts adopted in Russia after January 1, 2020 that addressed parents and offered support for families with children. These acts contain 78 institutional statements that we coded in accordance with the IGT rules, defining the attributes, objects, deontics and conditions in each sentence. Our results are as follows: 1) Russian family policy before and during COVID-19 pandemic can be divided into three stages, including the short-term second stage from the beginning of 2020 to the beginning of the pandemic. The most obvious changes in the three stages are seen in terms of the Objects and Conditions of the institutional statements. At the second and third stages we see a major expansion of support receivers (the Objects) as well as changes in the Conditions for the benefits gain. Conditions vary greatly and differ in terms of regularity of measure and the type of the payment granted; 2) Legal acts adopted do not always indicate clear Attributes, i.e., the subjects (federal and regional authorities) responsible for the implementation of the particular rule sometimes can hinder the implementation of the regulation; 3) Classification of the parameters of the main support measures in the framework and categories of the IGT analyses lead us to the probable concept of the information policy that would be clear to the beneficiaries of support measures.
\end{abstract}

Keywords: state family support system, family policy, COVID-19 pandemic, Institutional Grammar Tool

Raktažodžiai: valstybine paramos šeimai sistema, šeimos politika, COVID-19 pandemija, Institucinès gramatikos ịrankis

\section{Introduction}

Most of the social policy measures introduced during the COVID-19 pandemic aimed at facilitating the situation of different social groups (e.g., elderly people, parents, the unemployed, 
particular professionals) which was aggravated as a direct or indirect result of the pandemic. The inclusion of parents to this list was conditioned by the following reasons:

1. Childcare and school closures created the need for parents to take care of their children while working;

2. Displacement of some employees to distant workplaces impeded work-family reconciliation;

3. Due to social-distancing measures parents had limited opportunities to shift part of their parental duties to other individuals, e.g., grand-parents or nannies.

Russia takes quite a unique place in the range of countries that responded to the pandemic situation (Koslowski et al., 2020) with changes in its family policy. It is related to the development of the Russian family policy, which coincided with the pandemic situation to some extent. Situated within the last two years, the following stages in this development can be defined:

1. 2019 - the beginning of the implementation of the national project "Demography". This project of the federal scale was approved in accordance with the National Development Goals adopted in 2018. The project put previously existing benefits, such as maternity capital for the second child, allowances for families having children under the age of 1.5 and some others, at a new level. It also put the problem of the professional occupation of women having children under 3 at the national level.

2. 15 January 2020 to March 2020 (the beginning of pandemic). On 15 January 2020, the President of Russia delivered his annual Address to the Federal Assembly. An essential part of this annual Address was devoted to maternity and children support. A group of principally new measures was announced: maternity capital paid not only for the second child as it used to be earlier, but also for the first child; monthly payments for children from 3 to 7 years old in families whose income is lower than the regional minimum income.

3. March 2020 - onwards. The following new measures have been introduced during this period: payments for children from 3 to 16 (two times in this period); an additional payment to the unemployment allowance for parents who lost their jobs in this period and who have children under 18; additional payments for children under 3 years old.

Among the key parameters of the comparative family policy research Zagel and Lohmann (2020) distinguish the following ones: 1) the main family policy addressees; 2) the caregiver and/or the care receiver as the main policy focus; 3 ) the numbers of family policy "vectors" (Zagel \& Lohmann, 2020, p. 120; McCarthy \& Edwards, 2010). Since family policy is a cross-cutting policy area (Lewis, 2008, p. 308) (it is connected to a number of problems of communities, for example, birth rate, poverty, gender inequality and others), the improvement of family policy, the comparative research of the policy itself and its tools are critically important for the governments in different countries.

As Yang and Huang (2020) mention, despite numerous scientific discussions of the research methods pertaining to family policy, "there is no consensus in the literature on which specific policy instruments can be used to best describe a country's family policies" (Yang \& Huang, 2020, p. 4). Moreover, despite the choice of numerous variables for analysis (Elizalde-San Miguel et al., 2019; Daly \& Ferragina, 2018), Yang and Huang admit the internal characteristics of the policy itself are often not taken into account (Yang \& Huang, 2020). Our research can be regarded as a step to bridge this gap in the family policy research, since it includes the Institutional Grammar Tool (here and after IGT) analysis, which is quite new for this area. The choice of the above-mentioned period starting from 2019 as a period of active transformation of the family policy in Russia by means of the IGT analysis allows to frame the family policy at different stages, evaluate the dynamics of the family policy architecture and to reveal the changes in institutional statements viewed as internal characteristics of the policy itself.

Notably, until now IGT has been mostly applied to the analysis of environmental policy (see e.g. Novo \& Garrido, 2014; Clement et al., 2015; Watkins \& Westphal, 2016; Watkins, 2016; Carter et al., 2016; Heikkila \& Weible, 2018). This observation was made by Dunlop and her colleagues 
based on the reviewed publications using IGT indexed in Web of Science in the period 2017-2018 (Dunlop et al., 2019). Our analysis of the Scopus indexed publications from an earlier period and 2018-2020 led a similar conclusion: the thematic focus of half of those studies is connected to environmental issues. It is important to mention that IGT analyses are often combined with other research methods, such as telephone polls (Prior, 2018), interviews (Geary et al., 2019), social media analyses (Olivier, 2019) and others.

During the last three years, we have observed an emergence of projects and publications that apply IGT to broadly understood social policy issues. However, we are not aware of adequate studies that would apply IGT to social policy in the period of the COVID-19 pandemic ${ }^{1}$. Actually, IGT is a fruitful method in terms of social policies analyses since it helps to view the institutional design of the policy as a whole as well as to universalise the norms governing people's behaviour in different countries and time periods.

Hence, our research aims to analyse the changes of the family policy internal characteristics - specifically, state support to families having children - in the year preceding the pandemic and during the COVID-19 pandemic. Our research contributes to several directions: firstly, it widens the scope of the family policy research by considering its internal characteristics in one of the countries; secondly, it shows the opportunities of the application of IGT analysis to one of the most important social policy areas; thirdly, it demonstrates the potentials of the family policy IGT analysis in the highly dynamic situation of the COVID-19 pandemic.

\section{Method and data used}

Institutional Grammar Tool was first introduced by Crawford and Ostrom (Crawford \& Ostrom, 1995). In essence this is a method of an institutional analysis with the focus on institutional statements (i.e., 'shared linguistic constrains' (Crawford \& Ostrom, 1995) that govern people's behaviour and that take the form of norms, rules and strategies. In the course of IGT analysis the following components are defined in the statements (see, e.g., Siddiki et al., 2012; Tschopp et al., 2018; Angulo-Cázares, 2018):

a) Attributes, i.e., agents to whom an institutional statement is addressed;

b) Objects (animate or inanimate), i.e., the subjects of the actions;

c) Deontic, i.e., the level normative value of the statement;

d) Aim, i.e., action regulated by the statement;

e) Conditions define circumstances (territorial, temporary, procedural) under which the statement should be enacted or limitations for the action to be exercised;

f) Or else defines the consequences of not obeying the statement.

Both legal acts and other types of written texts (including also transcribed interviews) can be regarded as a source for IGT analysis. In some cases, these sources of information are taken together for complex IGT analyses (see, e.g. Pacheco-Vega, 2020) that allow to get a more full-fledged assessment of the situation and compare rhetoric in different types of initial data. As Dunlop and her colleagues (year) mention, while observing the publications with IGT from the last 10 years, this method is rarely applied to administrative procedures; therefore, the application of this method can offer new possibilities and is in high-demand.

An updated version of IGT, i.e., Institutional Grammar Tool 2.0 (Frantz \& Siddiki, 2020), offers more space to analyse different institutional configurations, for example, nesting of statements (the set of several norms related together) or constitutive statements (norms that offer definitions or establish the system and its actors). In the present paper, we applied this version.

For the purposes of our study we collected legal acts that cover issues of family support and child care during the COVID-19 pandemic in Russia. Measures of family policy and social support

\footnotetext{
${ }^{1}$ One of the few exceptions is the Policydemic project, initiated by Prof. Anna Kurowska and Bartosz Pieliński, scientists at the Warsaw University. The project focuses on comparative IGT analyses of COVID-19 regulations in the field of social policy.
} 
are matters of shared competence of the Russian Federation and its constituent units. Hence these matters can be governed both by federal legislation and regional legislation. Moreover, municipal (local) acts can also stipulate additional support measures for the residents of municipality in case the local budget allows. Therefore, the legislation in the given research field includes three tiers that are hierarchically related to each other. However, taking into account the highly centralised nature of the Russian Federation and financial incapacity of most municipalities to grant additional support, we decided to focus on the federal tier first. Thus, we analysed the federal legal acts adopted at three stages of the development of Russian family policy described above, and defined the changes that took place in this field of social policy during the pandemic.

In the course of the analysis we identified eleven legal acts that fit the subject area: two Federal laws, three President's Decrees and five Government's Ordinances. The system of Russian legislation presupposes that President's Decrees shall comply with the Federal laws that set forth basic rules in a particular area, while Government's Ordinances further delineate the procedures required to implement the Law or the Decree. Before 2020 the main Law that governed public support to families having children was Federal law No. 256-FZ of 2006 "On additional measures of state support to families having children". This Federal law provides so-called maternity capital to families having their second or third child and is applied uniformly in the whole Russian Federation. A detailed framework of the architecture of the state support to families having children in Russia in 2019 is reflected in Figure 1.

Chronologically, the first act that aims to provide additional support measures to families with children is President's Decree No. 199 "On additional measures of governmental support to families having children". It stipulates a monthly monetary payment to children from 3 to 7 years old in families whose median income is lower than the living wage. The particular amount of the payment depends on the living wage in the region and shall be set forth by regions. The payments shall be financed by both federal and regional budgets.

Following the President's Decree, the Government adopted Ordinance No. 384 "On the main requirements to the order of monthly monetary payment entitlement to children of 3 to 7 years old, approximate list of documents required for the entitlement and the form of the application to the entitlement" which sets forth the main requirements to the granting and payment of the additional support measures. A list of documents necessary for the granting of the measure and the draft of an application form are included.

Federal law No. 104-FZ, which was adopted on April 1, 2020, governs the peculiarities of counting the temporary disability allowance and providing a monthly payment to the first or second child (born or adopted). This Law has simplified the procedure for getting a monthly payment to the first or second child, stating that from April 1, 2020 to October 1, 2020 the payment shall be granted without submitting the application as was previously required by Federal law "On monthly payments to families having children".

The following President's Decree on the matter, i.e., "On additional measures of social support to families having children", was adopted on April 7, 2020 and provided monthly payments of 5000 rubles (approx. 55 EUR) to every child under three years old for the period April-June 2020. The rules of the payment according to this Decree were adopted by the Government's Ordinance No. 474 "On the Rules of providing monthly payment to families entitled to maternity (family) allowance". The Ordinance was amended twice, i.e., in May and June 2020; both amendments were related to the adoption of another President's Decree described below.

The President's Decree of June 23, 2020 No. 412 "On the payment to families having children" set forth another support measure aimed at families having children aged from 3 to 16 . The lump sum payment is 10000 rubles (approx. 110 EUR). The order of payment and application are governed by Government's Ordinance No. 474 as amended.

Another Government's Ordinance of March 31, 2020 No. 383 amended several Ordinances in order to simplify the order of usage of the so-called "maternity capital" (maternity allowance) for the proscribed needs. 


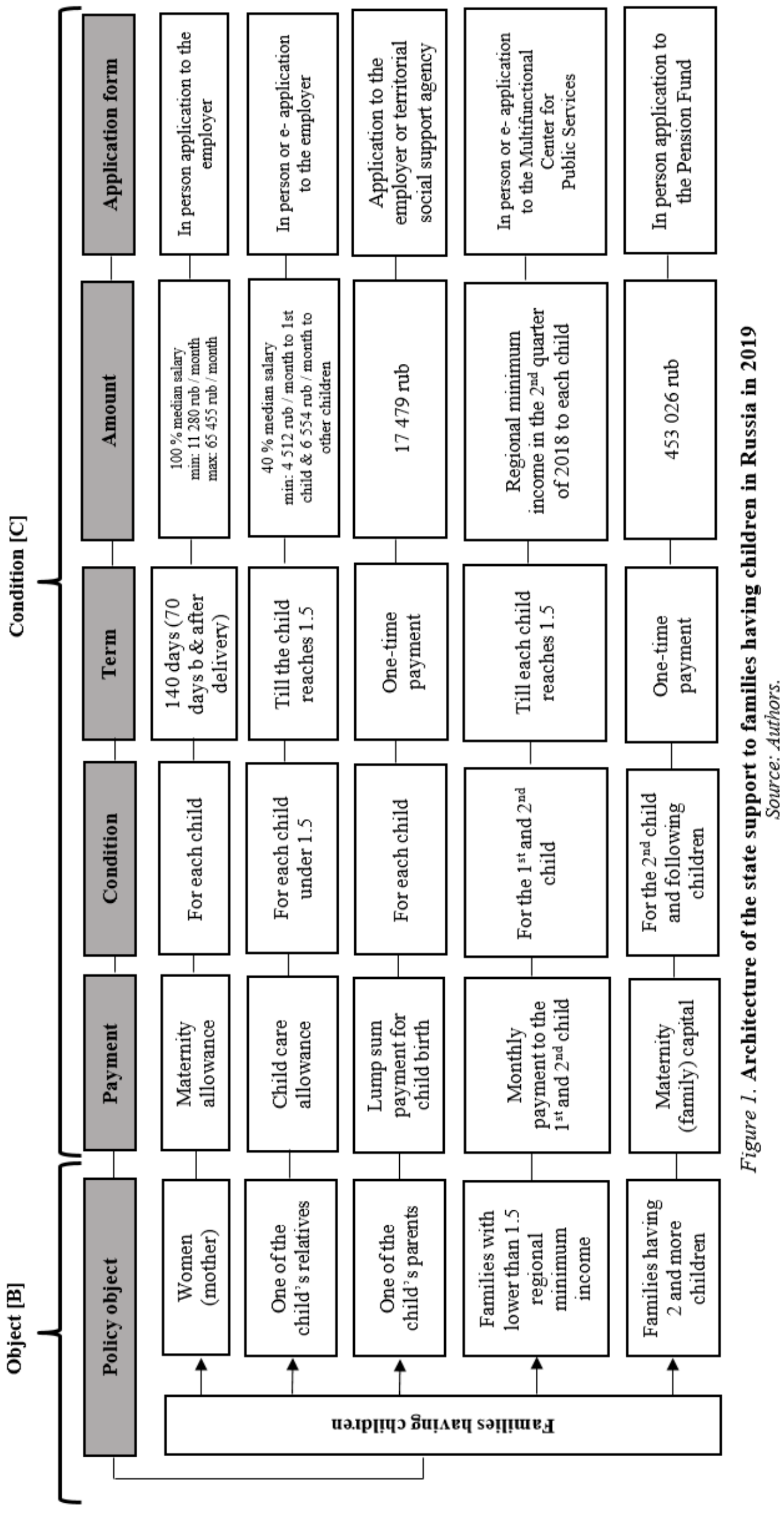


The provisions of the acts mentioned above were coded and analysed in accordance with the Institutional Grammar Tool 2.0.

We identified 78 institutional statements in the abovementioned legal acts. The majority of the statements are contained in the Government's Ordinances while the President's Decrees usually contain from 2 to 8 institutional statements. Following the Institutional Grammar Tool, we coded the statements specifying the addressee of the rule as the Attribute, the normative value of the regulation as Deontic, the action to be taken, or forbidden to be taken, or allowed to be taken as the Aim, the object of the action as the Object and also specifying the conditions of the action to be followed and the form of responsibility for the rule violation, if any, as Or else.

To illustrate the IGT coding method, below we provide an example using President's Decree No. 249 "On additional measures of social support to families having children". Although the Decree contains 5 provisions (clauses), only two general institutional statements could be identified. The first Decree's provision includes an executive order to provide monthly payments of 5000 rubles to the categories entitled. Clause 2 further clarifies who is entitled to the support, thus specifying the Object. Clause 4 stipulates the body responsible for the payment, thus defining the Attribute. Clause 5 contains an operative provision on entry into force and is not relevant for coding in our study. Therefore, clauses 1, 2, 4 and 5 taken together provide us with the following statement: "The Pension Fund of Russia shall provide monthly payments of 5000 rubles to each child up to 3 years old that is a Russian citizen".

Table 1. Example coding of the statement "The Pension Fund of Russia shall provide monthly payments of 5000 rubles to each child up to 3 years old that is a Russian citizen"

\begin{tabular}{|c|c|}
\hline COMPONENT & PART OF THE STATEMENT \\
\hline Attribute & Pension Fund of Russia \\
\hline Object & $\begin{array}{c}\text { Payment of 5000 rubles (direct object) to each child up to 3 years old that is a } \\
\text { Russian citizen (indirect object) }\end{array}$ \\
\hline Deontic & Shall \\
\hline Aim & Provide \\
\hline Condition & Monthly \\
\hline Or else & \\
\hline
\end{tabular}

Source: Authors.

\section{Results and Discussions}

The results of the legal acts analysed using IGT 2.0 show significant changes in the institutional design of the family support policy in Russia in the given period. The changes in the architecture of the support measures can been viewed in Figures 2 and 3, where Figure 2 demonstrates the core of the changes that took place, i.e., the shift in the objects of the family policy (receivers of measures) and various conditions to gain support. Figure 3 shows the dynamics of the process, covering all three periods of the development of family support in Russia.

78 institutional statements that were coded and analysed vary in terms of Objects, Aims and Conditions, but can be summarised in terms of Attributes, Deontics and responsibility clauses (here and after - Or else). The change in Objects and Conditions are summarised in Figure 2. The summary of the statements based on Attributes, Deontics and Or else is provided in Table 2.

Table 2. Summary of the statements based on Attributes, Deontics and Or else clauses

\begin{tabular}{|c|c|}
\hline COMPONENT & OPTIONS IN THE STATEMENTS \\
\hline Attribute & $16-$ citizens/ 62 - governmental bodies \\
\hline Deontic & $8-$ may/ 5 - should/ 65 - shall \\
\hline Or else & $76-$ none/ 2- clauses that refer to other legal acts establishing liability \\
\hline
\end{tabular}

Source: Authors. 


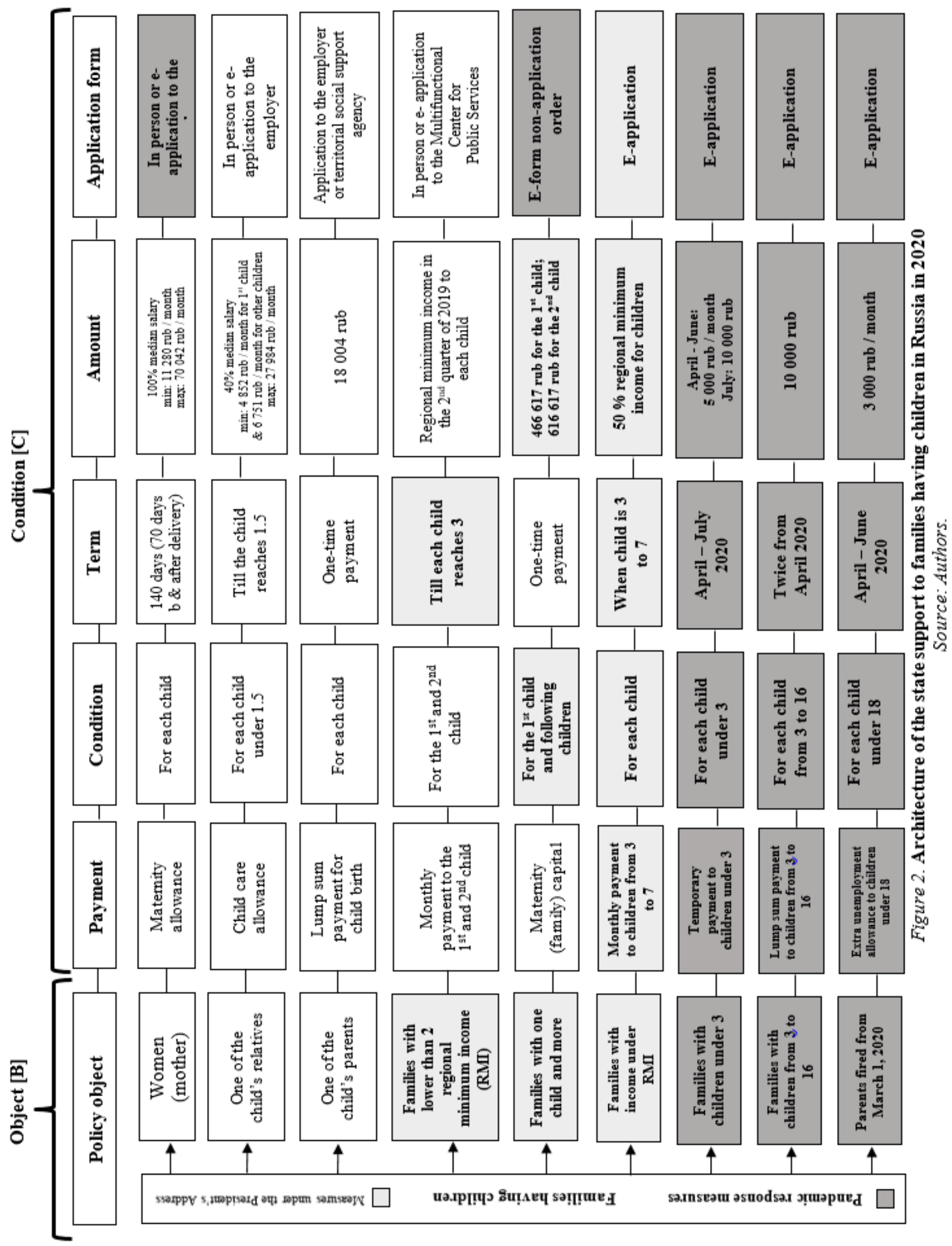



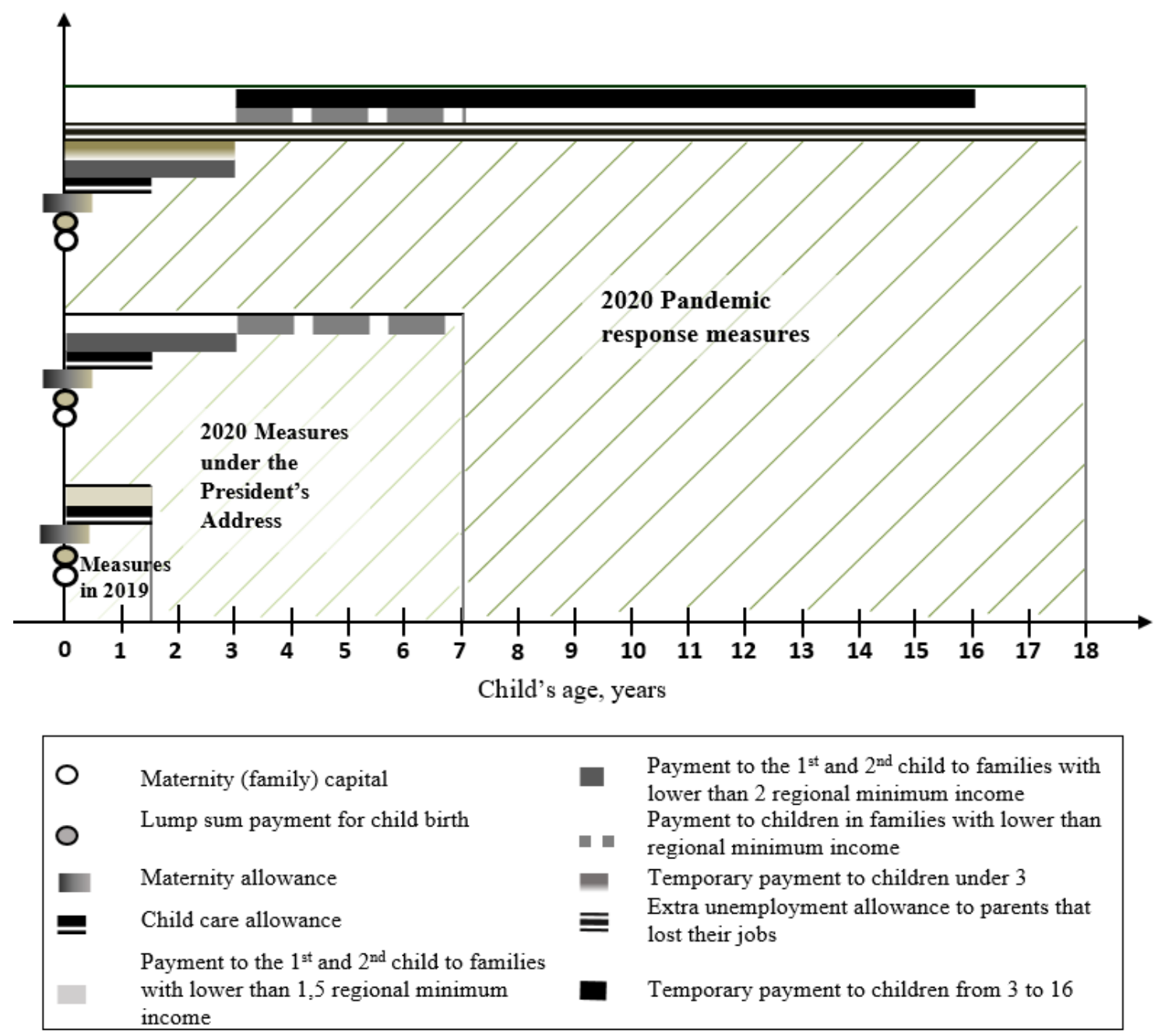

Figure 3. Dynamics of the state support to families having children in 2019-2020 Source: Authors.

As Figure 2 demonstrates, three stages of the family policy development can be distinguished based on the objects of the institutional statement (the receivers of the support measures). We can find a gradual, although quite rapid in time, expansion of the objects of family support. In 2019, we could find only one category of receivers (the mother or relatives who substitute the mother), while in the course of the second stage defined three new objects were added and three more objects were added in the course of the period of the pandemic.

One more major change that the analysis demonstrates is the change in Conditions. Figure 2 shows that the Conditions as such are various. They include the type of payment, its amount, the term, procedure of application and also the age and number of children that entitle the parents to the payment. The analysis of the Conditions reveals that measures taken at the second stage, i.e., in order to implement the President's Address, offer support for younger children and provide the support on a regular basis, while the third stage (pandemic) support measures are of a temporary nature, include lump sum payments and are granted to parents almost irrespective of the age of the child. These changes indicate the flexibility of the family policy taken by the state.

The wording of the Aim in the institutional statement can vary, but the point of the statement is usually to provide the support measure. Most institutional statements address the receivers of support measures as Objects and different governmental bodies as Attributes (see Table 1). Thus, although the regulations provide entitlement to citizens, they do not address citizens directly, but rather give certain orders to governmental bodies in order for the latter to provide the entitlement to citizens. 
The most frequent Attributes of the statements are the Government of Russia and the Pension Fund of Russia. As for the Government, it is obliged (the Aim) to finance the monetary obligations and stipulate particular requirements for the payment entitlement. The Pension Fund is in charge of the payment implementation and thus works with citizens directly receiving applications and taking decisions on the entitlement. Usually, the President's Decree stipulates the general rule on entitlement which is further clarified either by the Government or by regional bodies. Such an approach requires the citizen to consult at least two (usually more) legal acts.

As for the structure of Deontics, it relates directly to a certain Attribute and thus is quite clear. The majority of the Deontics took a strong prescriptive form, i.e., "shall". This form requires to strictly follow the rule and an imperative regulation method. Such a method is used in relation to the governmental bodies that are Attributes of the majority of statements. The much weaker Deontic "may" is used in relation to the citizens who may choose the form of action in some cases. This approach complies with the general legal tradition in the Russian legislation.

The Deontic "should", a recommendation rather than an explicit order, was used five times to address the Governors of regions. This point deserves a separate remark. For example, the President's Decree No. 199 "On additional measures of governmental support to families having children"; which stipulates a monthly monetary payment to children from 3 to 7 years old, recommends that Regional Governors adopt eligibility rules. Therefore, the rule implementation depends on whether the Governors choose or do not choose to follow the recommendation. The Deontic "should" in this case is preconditioned by the competence of the federation and the regions enshrined in the Constitution: the Federal Government cannot oblige regions to stipulate certain social support measures since it can be done by regions voluntarily and if the region can finance the obligation. In our case, the Federal Government provides co-financing to regions; however, regions also bear the burden and hence cannot be forced to take action.

The last point in terms of the IGT-based analysis is connected to the sanctions included to the family support regulations ("Or else" component). As can be seen in Table 2, none of the coded statements provide sanctions for the violation of the rule. Two statements contain reference clauses saying that "responsibility for the rule violation is provided by the Russian legislation". The IGT method provides that the statements without "Or else" component cannot be regarded as rules but rather classified as strategies or norms (Siddiki et al. 2012). However, we cannot agree that all the statements analysed do not amount to rules in the meaning of Russian law. It is true that the majority of the normative provisions in the Russian legislation do not include particular responsibility measures for the breach of these provisions. The reason for such an approach is given in administrative and criminal legislation of Russia, which provide general responsibility measures for particular offences or crimes that unite different types of misbehaviour.

\section{Conclusion}

The IGT analysis of the state support system to families having children in Russia in the period of the COVID-19 pandemic has led us to the following conclusions:

1. Russian family policy experienced major changes during the period of the research. It can be divided into three stages with its own peculiarities. The most obvious changes in the three stages of the Russian family policy are seen in terms of the Objects and Conditions of the institutional statements. At the second and third stages a major expansion of support receivers (Objects) as well as changes in the Conditions for the benefits gain can be seen. Conditions vary greatly and differ in terms of regularity of measures and the type of the payment granted. The Conditions show that the measures taken within the framework of the President's Address are of a regular character and consist of bigger amounts, while pandemic measures providing temporary support are irregular and give small sums to a wider range of beneficiaries.

2. Although the adopted legal acts related to support for families during the COVID-19 pandemic provide certain social rights to citizens, they do not address citizens directly, but give particular orders to state bodies which provide the support to citizens. The legal acts adopted do not 
always indicate clear Attributes, i.e., the subjects (federal and regional authorities) responsible for the implementation of the particular rule, which sometimes can hinder the implementation of regulations.

3. Russian legislation aimed at family support during the pandemic contains limitations connected to the convenience of the perception of measures by their receivers. The reason for this inconvenience can be found in the formulations of the institutional statements in the legal acts, which, as IGT reveals, often lack an explicit attribute. The results of our analysis show that although the shift in family policy is obviously in favour of citizens, the legislation still needs clarification in terms of explicit Attributes and regulation of administrative procedures in one legal act. Classification of the main support measures parameters in the framework and categories of the IGT analyses leads us to the probable concept of the information policy that would be clear to the beneficiaries of support measures.

We see the following further prospects for our research: 1) further IGT analyses of the family policy dynamics in Russia (some statements of the Russian Government and negative demographic trends allow further policy changes); 2) international comparison of the family policy changes during the pandemic; formalisation of analysis by means of IGT allows to apply a uniform research method to different countries and establish both general trends and local peculiarities in the field of social policy towards families having children.

\section{Acknowledgement}

This paper is one of the outputs of the research project "Russian pronatalist policy: resources, effects, optimisation opportunities", supported by the Council on grants of the President of the Russian Federation, project no. NSh-2722.2020.6. The authors thank Anna Kurowska and Bartosz Pielinski from Warsaw University for the idea that inspired this study, as well as the valuable recommendations they provided to the authors.

\section{References}

1. Address from the President to the Federal Assembly. 2020. http://kremlin.ru/events/president/news/62582

2. Angulo-Cázares, R. (2018). Agency problems in basic education in Mexico: an institutional diagnosis. Convergencia, 25(77), 149-173.

3. Carter, D. P., Weible, C. M., Siddiki, S. N., \& Basurto, X. (2016). Integrating core concepts from the institutional analysis and development framework for the systematic analysis of policy designs: An illustration from the US National Organic Program regulation. Journal of Theoretical Politics, 28(1), 159-185.

4. Clement, S., Moore, S. A., Lockwood, M., \& Morrison, T. H. (2015). A diagnostic framework for biodiversity conservation institutions. Pacific Conservation Biology, 21(4), 277-290.

5. Crawford, S. E., \& Ostrom, E. (1995). A grammar of institutions. American political science review, 89(3), 582600.

6. Daly, M., \& Ferragina, E. (2018). Family policy in high-income countries: Five decades of development. Journal of European Social Policy, 28(3), 255-270.

7. Dunlop, C. A., Kamkhaji, J. C., \& Radaelli, C. M. (2019). A sleeping giant awakes? The rise of the Institutional Grammar Tool (IGT) in policy research. Journal of Chinese Governance, 4(2), 163-180.

8. Elizalde-San Miguel, B., Gandasegui, V. D., \& García, M. T. S. (2019). Family Policy Index: A tool for policy makers to increase the effectiveness of family policies. Social Indicators Research, 142(1), 387-409.

9. Federal Law No. 104- $\Phi 3$ of April 1, 2020, "On the Specifics of Calculating Benefits for Temporary Disability and Making Monthly Payments in Connection with the Birth (Adoption) of the First or Second Child." http://publication.pravo.gov.ru/Document/View/0001202004010077

10. Federal Law No. 256-Ф3 of December 29, 2006, “On Additional Measures of State Support to Families Having Children.” http://www.kremlin.ru/acts/bank/24820

11. Frantz, C. K., Siddiki, S. N. (2020). Institutional Grammar 2.0 Codebook. https://arxiv.org/abs/2008.08937

12. Geary, J., Reay, T., \& Bubela, T. (2019). The impact of heterogeneity in a global knowledge commons: Implications for governance of the DNA barcode commons. International Journal of the Commons, 13(2).

13. Government's Ordinance No. 384 of March 31, 2020, “On the Approval of the Basic Requirements for the Procedure for the Appointment and Implementation of a Monthly Cash Payment for a Child Aged 3 to 7 Years, Inclusive, an Approximate list of Documents (Information) Required to Assign the Specified Monthly Payment, and a Standard Application Form for Its Appointment.” http://publication.pravo.gov.ru/Document/View/0001202004030035 
14. Government's Ordinance No. 474 of April 9, 2020, "On Approval of the Rules for the Implementation of Monthly Payments to Families Eligible for Maternity (Family) Capital." http://publication.pravo.gov.ru/Document/View/0001202004100037

15. Heikkila, T., \& Weible, C. M. (2018). A semiautomated approach to analysing polycentricity. Environmental policy and governance, 28(4), 308-318.

16. Koslowski, A., Blum, S., Dobrotić, I., Kaufman, G., \& Moss, P. (Eds.). (2020). 16th International Review on Leave Policies and Related Research. FernUniversität in Hagen.

17. Lewis, J. (Ed.). (2008). Children, changing families and welfare states. Edward Elgar Publishing.

18. McCarthy, J. R., \& Edwards, R. (2010). Key concepts in family studies. Sage Publications.

19. Novo, P., \& Garrido, A. (2014). From policy design to implementation: an institutional analysis of the new Nicaraguan Water Law. Water Policy, 16(6), 1009-1030.

20. Olivier, T. (2019). How do institutions address collective-action problems? Bridging and bonding in institutional design. Political Research Quarterly, 72(1), 162-176.

21. Pacheco-Vega, R. (2020). Governing Urban Water Conflict through Watershed Councils_-A Public Policy Analysis Approach and Critique. Water, 12(7), 1849.

22. President's Decree No. 199 of March 20, 2020, “On Additional Measures of State Support for Families with Children.” http://publication.pravo.gov.ru/Document/View/0001202003200014

23. President's Decree No. 204 of May 7, 2018, “On National Goals and Strategic Objectives for the Development of the Russian Federation for the Period up to 2024." http://publication.pravo.gov.ru/Document/View/0001201805070038

24. President's Decree No. 249 of April 7, 2020, “On Additional Measures of Social Support for Families with Children.” http://publication.pravo.gov.ru/Document/View/0001202004070063

25. Prior, J. (2018). Factors influencing residents' acceptance (support) of remediation technologies. Science of the total environment, 624, 1369-1386.

26. Siddiki, S., Basurto, X., \& Weible, C. M. (2012). Using the institutional grammar tool to understand regulatory compliance: The case of Colorado aquaculture. Regulation \& Governance, 6(2), 167-188.

27. Tschopp, M., Bieri, S., \& Rist, S. (2018). Quinoa and production rules: how are cooperatives contributing to governance of natural resources?. International Journal of the Commons, 12(1).

28. Watkins, C. (2016). Studies in Indo-European legal language, institutions, and mythology (pp. 321-354). University of Pennsylvania Press.

29. Watkins, C., \& Westphal, L. M. (2016). People don't talk in institutional statements: A methodological case study of the institutional analysis and development framework. Policy Studies Journal, 44(S1), 98-122.

30. Yang, Q., \& Huang, J. (2020). Content Analysis of Family Policy Instruments to Promote the Sustainable Development of Families in China from 1989-2019. Sustainability, 12(2), 693.

31. Zagel, H., \& Lohmann, H. (2020). Conceptual approaches in comparative family policy research. In The Palgrave Handbook of Family Policy (pp. 119-139). Palgrave Macmillan, Cham.

Anna Bagirova, Evgeniya Kuznetsova, Natalia Blednova

\section{Valstybės parama šeimoms, turinčioms vaikų, Rusijoje pandemijos metu: institucinės gramatikos analizè}

\section{Anotacija}

Šiuo laikotarpiu COVID-19 pandemijai būdingi aktyvūs ịstatymų leidybos procesai, skirti sveikatos apsaugai ir įvairių kategorijų gyventojų palaikymui daugelyje pasaulio šalių. Nuo $2019 \mathrm{~m}$. dèl neigiamų demografinių tendencijų Rusija aktyviai pertvarkè valstybès paramos šeimoms, turinčioms vaikų, sistemą. Ši tendencija sustiprejo pandemijos metu. Mūsų tyrimu siekiama išanalizuoti vidines šeimos politikos ypatybes, t. y. valstybės paramą šeimoms, turinčioms vaikų, per metus prieš pandemiją ir per pandemijos laikotarpị. Apsvarstome šeimos politikos architektūros dinamiką naudodamiesi institucine gramatikos įrankių analize ir parodome galimybes naudoti tokių analizių rezultatus labai dinamiškoje COVID-19 pandemijos situacijoje.

Mes išanalizavome 11 federalinių teisès aktų, priimtų Rusijoje po 2020 m. sausio 1 d., kurie buvo skirti tèvams ir siūle paramą šeimoms su vaikais. Šiuose aktuose yra 78 instituciniai teiginiai, kuriuos užkodavome pagal IGT taisykles, kiekviename sakinyje apibrěždami atributus, objektus, deontiką ir sąlygas. Mūsų tyrimo rezultatai yra tokie: 1) Rusijos šeimos politiką prieš ir per COVID-19 pandemiją galima suskirstyti ị tris etapus, įskaitant trumpalaikius. Antrasis etapas: nuo $2020 \mathrm{~m}$. pradžios iki pandemijos pradžios. Akivaizdžiausi pokyčiai trijuose etapuose matomi 
atsižvelgiant ị institucinių pareiškimų objektus ir sąlygas. Antrame ir trečiame etape matome didelę paramos gavėjų (objektų) plètrą, taip pat pokyčius išmokų prièmimo sąlygose. Sąlygos labai skiriasi dèl priemonès reguliarumo ir suteiktos išmokos rūšies; 2) Priimtuose teisès aktuose ne visada nurodomi aiškūs atributai, tai yra subjektai (federalinès ir regioninės valdžios institucijos), atsakingi už konkrečios taisyklès igyvendinimą, o tai kartais gali trukdyti igyvendinti reglamentą; 3) Pagrindinių paramos priemonių parametrų klasifikavimas pagal IGT analizès struktūrą ir kategorijas leidžia nustatyti galimą informacijos politikos koncepciją, kuri būtų aiški paramos priemonių gavëjams.

Anna Bagirova, Professor at the Department of Sociology and Public Administration Technologies, Ural Federal University, Russia

E-mail: a.p.bagirova@urfu.ru

Evgeniya Kuznetsova, Assistant Professor at the Department for Theory, Methodology and Law Support of State and Municipal Administration, Ural Federal University, Russia

E-mail: ev.kuznetsova@urfu.ru

Natalia Blednova, Analyst at the Center for Regional Economic Research, Ural Federal University, Russia

E-mail: $\underline{\text { n.d.blednova@urfu.ru }}$

Anna Bagirova, profesorè, Sociologijos ir viešojo administravimo technologijų katedra, Federacinis Uralo universitetas, Rusija

El. paštas: a.p.bagirova@urfu.ru

Evgeniya Kuznetsova, docentè, Teorijos, metodologijos ir teisinès paramos šalies ir savivaldos administracijoms katedra, Federacinis Uralo universitetas, Rusija

El. paštas: ev.kuznetsova@urfu.ru

Natalia Blednova, analistė, Regioninės ekonomikos tyrimų centras, Federacinis Uralo universitetas, Rusija

El. paštas: n.d.blednova@urfu.ru 